\title{
2.6 ECONOMIC PLANNING ON FARMS - RELEVANCE, SPECIFIC CHARACTER, SCOPE
}

\begin{abstract}
Basic questions a farmer running a commercial farm has to keep asking himself are as follows: "What should I produce?" and "How should I manage production in order to achieve the defined target?". The questions are still not easy to be answered, even despite the evident progress made. But it can be helpful to some extent to implement a proper process of economic and production planning on farms. As studies carried out at the Department of Economics and Organisation of Enterprises at Warsaw University of Life Sciences reveal, Polish farmers (regardless of their education, age, farm area and keeping accounts) believe that planning is necessary. They justify this fact in first place with better organisation of work and opportunities to earn higher income. Selection of proper parameters (related to production, prices and technology) is a relatively vital issue arising in development of plans.

The main objective of this article is to present methods of planning on family milk farms in Poland. Attention will be also drawn to methods of generating parameters required for planning in accordance with German solutions proposed by KTBL (Das Kuratorium für Technik und Bauwesen in der Landwirtschaft). The solutions are innovative and useful. This paper is a part of the research project entitled: "Economic and social conditions for regional changes in milk production and processing" (no.: 0890/B/H03/2010/39) funded by the Ministry of Science and Higher Education.
\end{abstract}

Keywords: farms, planning, standards and norms, standard costs

\section{INTRODUCTORY ISSUES}

The issue of planning in business entities has always been of central importance to the management system. As it was once remarked, it allows "order in a business activity" and makes it possible to take decisions not in a situation of pressure, but with enough time and space for making an optimal decision (Manteuffel, 1967). Planning is one of the basic processes thanks to which goals and methods of their implementation can be defined. Without plans, managers (owners) of business entities would be clearly limited in organizing activities and goal-oriented use of resources (Stoner, 2011). Planning has various definitions in reference literature, most frequently it is treated as a system process.

The process of planning is indispensible in most business entities, which operate on different levels of complexity of implemented processes. As studies carried out at the Department of Economics and Organisation of Enterprises at Warsaw University of Life Sciences reveal, Polish farmers (regardless of their education, age, farm area and keeping accounts) believe that planning is necessary. They justify this fact in first place with better organisation of work and opportunities to earn higher income (Bereżnicka, 2000).

The main objective of the article is to present methods of planning on family milk farms in Poland. Attention will be also drawn to methods of generating parameters required for planning in accordance with German solutions proposed by KTBL (Das Kuratorium für Technik und Bauwesen in der Landwirtschaft). This paper is a part of the research project entitled: "Economic and social conditions for regional changes in milk production and processing" (no.: 0890/B/H03/2010/39) funded by the Ministry of Science and Higher Education. 


\section{SPECIFIC CHARACTER OF THE PLANNING PROCESS ON FARMS}

Agricultural economists rather agree that agriculture is a branch of economy exposed to specific environmental climate conditions and socio-cultural conditions (Tomczak, 2004). The specific role of agriculture is attributable also to the fact that it is a source of the most important product of humanity, which is food. As J. Wilkin points out "It doesn't matter how long and complex the so called food chain is, how industrialised food production is and what a small part of the value of a final food product is attributable to a farmer. (...) Without the products, which are effects of a farmer's work, the whole food chain is not justified" (Wilkin, 2005). Any differences between agriculture and other branches of national economy arise due to the character of agricultural production. In case of running this type of production, we make use of biological properties of plants and animals.

The production process takes place in organisms of living creatures, which are plants and animals, and the role of the human, who is the formal producer, boils down to creating the best possible conditions so that the living creatures are willing to develop, reproduce and put on weight (Manteuffel, 1987). In agricultural production (as opposed to most non-agricultural activities), the land continues to be an important production factor. Due to its specific characteristics (non-reproducibility, immobility, potential indestructibility, limited production capacity) agriculture has to abide by its own set of rules. Agriculture exhibits specifically a three-factor function stressing that productivity of the capital factor and labour factor is affected by the productivity of the land factor. The limited production capacity of the land translates, in turn, into a limited productivity of labour and capital (Rembisz, 2008). When an agricultural production is run, the land becomes a centre of production, and not a place such as a place (mostly) in other sectors of economy. It means that in agriculture the land is directly involved in the production, transferring fertilizer compounds onto plants, which grow on it. The possession of the land has been a basis for well-being and a source of social privileges for ages. This in turn gives rise to emotional attachment to the land known as patrimony, and in a broader sense - the homeland.

In running agricultural production, a critical role is assigned to the human - producer, who is a careful observer of the life of plants and animals, required to create for them conditions for the most efficient development (Manteuffel, 1987). The human in the agricultural production process acts like an entrepreneur, having at his disposal a great number of minor mini-producers, which are plants and animals. A farmer has to watch the course of life of plants and animals, and based on that, he has to create for them optimal conditions for development. In most non-agricultural professions it is possible to leave the profession for a certain period of time, in specific branches of national economy it is also possible to temporary suspend production. In agriculture, though, it is not possible. That is why it is typical of the profession of a practicing farmer, in particular in animal production, that this job exhibits continuity throughout the year. This feature of agricultural production contributes to the fact that a number of people leave the profession. Prof. R. Manteuffel wrote: “... A real (I would say genuine) farmer shapes living plant and animal organisms. He can be to some extent compared to an artist creating works of art; he feels a joy, which is similar to that of the artist, who succeeds in producing something beautiful. Like an artist, he is also keen on obtained yields..." (Manteuffel, 1987).

Agricultural production is run in business entities called farms. They are the oldest organisational form of the human business activity. In the historic development, they experienced a long way of evolution. In early feudalism, they were organized as subsistence farms (feudal farms, peasant's farms). Then, they were run as semi-subsistence farms, loosely linked to the developing market. Under the conditions of developed market economy, they have been gradually transforming into agricultural companies. The notion of a farm is 
variously defined in reference literature. According to the Polish Civil Code, a farm is considered to be "agricultural land with forest land, buildings and parts of them if they constitute an organised business entity and with rights and obligations arising from running a farm" (the Civil Code). Polish economists stress that attempts should be made to distinguish agricultural companies from farms. According to Ziętara a farm is "a separate organisational production entity representing a set of three production factors: land, labour, capital (production resources), aimed at production of agricultural products. Talking of a farm, we do not go into details over how produced goods will be allocated, whether they will be used on a farm or allocated to satisfy the needs of a farmer and his family. A farm is a technical and organisational entity operating with a view to making agricultural products. An agricultural company, in the view of Ziętara, "is a business entity separated not only in terms of organisation, but also economically and legally, operating with a view to making agricultural products and providing agricultural services for sale. In companies, thus, production is commercial" (Ziętara, 1998). Farms (agricultural companies) in Poland and other European countries are mostly family businesses (Kowalczyk, 2011).

As it is defined by Tomczak: "a family farm is an independent production entity, in which the basic production factors belong to the owner (family), who performs managerial functions, work is done mainly by the owner and his family; ownership and management are passed down from generation to generation; a household is not separated from a production entity, and the farm generates income" (Tomczak 1998). In addition, A. Woś assigns to a family farm "a pursuit of a long-term goal, which is providing for a family and creating conditions for development of future generations, and he points out that a farmer on a family farm achieves a multi-component goal. He strives to maximise current income, but at the same time he has to offer employment to all family members" (Woś 1996). In Poland, it is proposed to legally establish family farms as a basis of agriculture. The Parliament $\left(11^{\text {th }}\right.$ April 2003) enacted the act on national agricultural constitution in Poland (Journal of Laws 2003.64.592). In the above-mentioned act, a family farm is considered to be an entity conducting an agricultural activity based on own labour resources (having appropriate qualifications) and having a specified area (from 1 to 300 ha of agricultural land). The fragment about the size of the area of agricultural land, constituting elements of a family farm, raises some doubt. It turns out that under present conditions (given the technology available) it is possible to run a bigger farm (than the one specified in the act) based on own labour resources.

Considering the specific features of agricultural production and farms (agricultural companies) the process of efficient planning (feasible activities) must allow for economic, environmental and social conditions. While preparing a plan of development for a family farm (agricultural company) family goals should be treated as a starting point, i.e. the agricultural activity should be planned keeping in mind the household. By defining common family objectives, it is easier to determine a vision of development of a farm and formulate strategic plans. In conducting the planning process on farms, it is not possible to forget the key specific character of agricultural production, which is the reliance on living organisms and natural environment. At present (years 2004-2012) more and more emphasis is placed on running agricultural production so as not to harm natural environment. Different environmental restrictions in the form of legal regulations are imposed on an agricultural producer. While planning his activity a farmer must keep that in mind and be aware that production risk resulting from variability and unpredictability of climate conditions is high. In developing plans, economic parameters, including pricing, are also of great importance. It is often the case when a farmer struggles with proper definition of product prices and production means in the plan. Too optimistic approach (high product prices), which is likely to appear on the 
market at the moment of preparing a plan, can make the plan unrealistic and difficult to implement (e.g.: maintenance of solvency).

However, it must be stressed that science, deriving information from economic practice, can offer better and better and more and more detailed proposals of production methods on farms, enabling achievement of planned targets. This situation arises due to the fact that most farms have been "producing" the same materials for ages, and given that, optimal methods for running this production are better understood.

\section{METHODS OF PLANNING ON FAMILY FARMS}

As it results from studies carried out at the Department of Economics and Organisation of Enterprises at Warsaw University of Life Sciences, plans prepared on farms can be differentiated based on two criteria: planning horizon and decision relevance (possibility of turning it back) on farms. These plans overlap because in most cases long-term plans are plans addressing more important (and frequently difficult to be turned back) decisions (Bereżnicka, 2000). Bearing in mind the presented criteria of division it can be stated (in general nomenclature) that farmers work out strategic plans, being in most cases long-term plans, and operational plans, which are short-term. Developed strategic plans depict a vision of a farm in the next few years. This point is presented in a relatively general manner. In most cases it boils down to defining volumes of generated production.

Operational plans are more concrete. They are often short-term (monthly, quarterly, annual) plans. In operational plans, it is essential to foresee a financial standing of a farm. Solvency control is particularly important. It is very important to answer the question: Will current payments made into a bank account related to the activity conducted be sufficient to meet current financing requirements? This calculation is so important among others due to the fact that on farms (in particular the ones focused on plant production) payments and withdrawals of monies are spread over time very unevenly. On plant production farms farmers are forced (because of the production technology) to purchase production goods mostly at the beginning of the year, whereas payments for sale of products are made already after harvests (the second half of the year).

Plans on farms are prepared using different computer programs. "FINPACK" is an interesting tool, making it possible to approach the planning process on farms in a comprehensive manner. While using this tool it is necessary to make several logical steps. The first one includes an analysis of the economic and production situation (for the last year) on a farm (FINAN). In this part it is possible to determine the value of assets and sources of financing them, efficiency of the conducted agricultural activity for the whole farm or respective production branches, and to analyse the solvency of the farm. The next step of using the "FINPACK" tool entails development of long-range and strategic plans (FINLRB). By means of the analysed tool a farmer can define several directions for development of the farm (direction of production and desired size of the activity). Having entered parameters, a farmer gets a comparison of different development directions in terms of economic aspects. The third part of the "FINPACK" program has an algorithm for planning current financial flows (FINFLO). It makes it possible to answer one of the key questions: Will current payouts be high enough to meet financial requirements? Summing up it can be stated that using the "FINPACK" program a farmer can answer three important questions:

1) Where am I? - i.e. what my farm looks like (balance of assets, economic and production analysis);

2) Where do I want to be? - i.e. which direction of farm development should be pursued to achieve the intended goals (definition of different strategies of a farm depending on goals and changes of the surrounding circumstances); 
3) How can I reach it? - i.e. will my own means be sufficient to implement planned changes, and if not, where to acquire money that is lacking (drawing up of a cash flow) (Bereżnicka, 1998).

\section{STANDARDS AND NORMS GENERATED BY "KTBL"}

Preparation of plans often involves the issue of reliability of input parameters, which will impact final arrangements. Thus, a question arises: where to obtain information (parameters) from to develop a plan properly? Reference literature mentions that they should include:

- average quantities from relevant facilities corresponding to specific conditions,

- quantities verified in practice and based on personal experience of a person drawing up a plan,

- quantities selected in a proper manner from reference literature (Ziętara, 1994).

In case of relying on parameters from relevant facilities, a risk arises as to the fact that we will repeat mistakes from previous years in the plan. Therefore, it seems that we should rely on reference literature and in particular on standards and norms specified based on theoretical premises. In reference literature an ex ante cost statement, basing on desired anticipated quantities we would like to reach in optimal organisation of production, is referred to as standard cost statement or postulated cost statement (Karmańska, 2011). Many authors, i.a. Skwarzyn S., Fedak Z, Karmańska A. point out those costs in this statement can be determined based on standard costs resulting from base standards (permanent ones) or current standards called currently binding standards.

In many counties in the world, standards and norms are in use, which define standard (normative) costs of the agricultural activity depending on environment conditions and technological solutions. In Poland, the issue was particularly intensively dealt with in the 1970s; afterwards, the issue has not been studied so intensively. A great contribution to this field has been made by employees of Warsaw University of Life Sciences, and in particular by Prof. Ryszard Manteuffel (1971), Prof. Florian Maniecki (1976) and Józef Żuk, Ph.D. (1986). In other countries works devoted to this issue are still being continued. IT technologies offer new opportunities in this respect. Parameters for planning on farms etc. are generated by the institution called "Das Kuratorium für Technik und Bauwesen in der Landwirtschaft" (KTBL) in Germany. The mentioned institute generates standard parameters for most agricultural activities conducted in different systems (conventional, ecological ones) and presents standard costs of engaging different combinations of machines. In the electronic base developed by KTBL the following parameters are available (as at 4.06.2012):

a) Parameters relating to outbuildings - investment expenditure and running costs of 162 models of greenhouses and plastic tunnels, 222 selected buildings for cattle, goats, sheep, horses, pigs, poultry and storehouses and warehouses;

b) Parameters relating to plant production economics and organisation:

- Detailed data for planning of plant production (production costs for selected activities depending on the anticipated yields level, quality of soils, field size, a set of machines used for cultivating procedures);

- Diesel oil requirement depending on a performed cultivating procedure, set of machines, firmness of soil, field size, distance between the field and farm centre;

- Expenditures and labour costs depending on a cultivating procedure, set of machines, firmness of soil, field size, distance between the field and farm centre;

- Costs of use and maintenance (depreciation, repairs, fuel) of approx. 1400 machines;

- Standard direct surpluses for respective regions and years.

c) Parameters relating to animal production economics and organisation: 
- Detailed data for planning of animal production (production costs for selected activities depending on the anticipated yields level, animal housing method etc.);

- Parameters for converting animals into the so called "livestock units";

- Detailed parameters related to the standards of "Animal welfare". The system describes and assesses 139 methods of housing cattle, swine, poultry and horses in terms of impact on environment and aspects of animal welfare.

- Organic fertilizers in animal production - composition, doses depending on a grown plant etc.

d) Parameters relating to garden economics and organisation - similar parameters as in case of plant production;

e) Parameters relating to renewable energy and environment.

It should be pointed out that under the analysed system, it is possible to additionally generate economic and production parameters for agricultural activities performed in an ecological system. In this paper, I will limit myself to presenting parameters generated under the KTBL system for two agricultural activities - cultivation of winter rape and raising of dairy cattle. In the KTBL electronic system, in the plant production tab, a user can define a type of activity for which s/he would like to make an economic calculation. Then s/he selects a cultivation system (ecological or conventional one), marks a cultivation system, field area, crop yield level, quality of soils.

Table 1. Statement of revenues and costs relating to cultivation of winter rape in a selected production technology in the KTBL (conventional production, direct drilling of seeds, average crop yield level, average quality of soils, a tractor with an engine power of $67 \mathrm{~kW}$ used in farming, distance between the field and farm of $2 \mathrm{~km}$ )

\begin{tabular}{|c|c|c|c|}
\hline Specification & Volume & Price (EUR) & Value (EUR) \\
\hline Value of potentially commercial production & $3.35 \mathrm{t} / \mathrm{ha}$ & $263.17 \mathrm{EUR} / \mathrm{t}$ & $881.62 \mathrm{EUR} / \mathrm{ha}$ \\
\hline Total & & & $881.62 \mathrm{EUR} / \mathrm{ha}$ \\
\hline Seed & $0.33 \mathrm{SU} / \mathrm{ha}$ & $229.80 \mathrm{EUR} / \mathrm{SU}$ & $75.83 \mathrm{EUR} / \mathrm{ha}$ \\
\hline Lime & $1.00 \mathrm{t} / \mathrm{ha}$ & $59.00 \mathrm{EUR} / \mathrm{t}$ & $59.00 \mathrm{EUR} / \mathrm{ha}$ \\
\hline Nitrogen and phosphorus fertilizers & $440.00 \mathrm{~kg} / \mathrm{ha}$ & $0.23 \mathrm{EUR} / \mathrm{kg}$ & 101.20 EUR/ha \\
\hline Phosphorus and potassium fertilizers & $360.00 \mathrm{~kg} / \mathrm{ha}$ & $0.20 \mathrm{EUR} / \mathrm{kg}$ & $72.00 \mathrm{EUR} / \mathrm{ha}$ \\
\hline Fungicides & & & $37.00 \mathrm{EUR} / \mathrm{ha}$ \\
\hline Herbicides & & & $77.00 \mathrm{EUR} / \mathrm{ha}$ \\
\hline Insecticides & & & 16.00 EUR/ha \\
\hline Water for sprinkler & $1.20 \mathrm{~m}^{3} / \mathrm{ha}$ & $2.50 \mathrm{EUR} / \mathrm{m}^{3}$ & $3.00 \mathrm{EUR} / \mathrm{ha}$ \\
\hline Insurance & 880.00 EUR/ha & 23.34 & $20.54 \mathrm{EUR} / \mathrm{ha}$ \\
\hline Interest on equity - 3 months & 115.39 EUR/ha & 0.04 & $4.62 \mathrm{EUR} / \mathrm{ha}$ \\
\hline Direct cost total & & & 466.19 EUR/ha \\
\hline Direct surplus & & & 415.43 EUR/ha \\
\hline Variable costs of machines & & & 85.89 EUR/ha \\
\hline Variable costs of human labour & $0.00 \mathrm{mh} / \mathrm{ha}$ & $7.00 \mathrm{EUR} / \mathrm{mh}$ & $0.00 \mathrm{EUR} / \mathrm{ha}$ \\
\hline Services & & & $73.23 \mathrm{EUR} / \mathrm{ha}$ \\
\hline Variable costs total & & & 625.31 EUR/ha \\
\hline Gross surpluss & & & 256.31 EUR/ha \\
\hline Fixed costs of machines & & & 139.32 EUR/ha \\
\hline Fixed costs of human labour & $4.24 \mathrm{rbh} / \mathrm{ha}$ & $15.00 \mathrm{EUR} / \mathrm{rbh}$ & $63.60 \mathrm{EUR} / \mathrm{ha}$ \\
\hline $\begin{array}{l}\text { Surplus above direct costs and costs of } \\
\text { labour performance }\end{array}$ & & & 53.39 EUR/ha \\
\hline
\end{tabular}

Source: own study based on http://daten.ktbl.de/dslkrtier/postHv.html

To determine standard costs of labour performance it is necessary to provide information about the level of mechanisation of labour and used tractor (engine power). A distance 
between the field and farm centre is important information, which is taken into account while generating analysed parameters. After specification of mentioned parameters, a user receives information about potential crop yield and its value and standard costs to be incurred in order to produce it. In case of mentioned winter rape (Table 1) potential crop yield is presented at the level of $3.35 \mathrm{t} / \mathrm{ha}$. The value of potentially commercial production to be obtained from one hectare cultivated with rape amounts to EUR 881.62. Costs are broken down into significant groups. The first one covers direct costs (seeds, mineral fertilizing, plant protection, insurance of plantation and cost being a calculated cost - interest on engaged capital. A difference between the production value and mentioned direct costs is called a direct surplus. In the presented calculation is reaches the level of $15.43 \mathrm{EUR} / \mathrm{ha}$. The next identified group entails variable costs. They include direct costs and variable costs of machines and human labour and external services (e.g.: concerning mechanisation) incurred due to cultivation. A difference between the production value and variable costs is called a gross surplus (in the analysed case it is $256.31 \mathrm{EUR} / \mathrm{ha}$ ). While adjusting the determined gross surplus by fixed costs of machines and human labour, we receive information about "a surplus above direct costs and labour performance" (53.39 EUR/ha). It should be stressed that the presented costs and revenues are standard ones. According to findings of experts in most cases it is necessary to incur specifically such costs (as at present) in order to produce a specific effect (crop yield).

Animal production is a branch of production on farms which is more complex than plant production. It is in part like processing (processing fodders produced on the farm) and buildings are required in the production process (under our climate conditions). Production of milk, which is analysed in this paper, is one of the most complex production activities on a farm. What is more, it is capital-intensive and requires human labour. Modern technologies of milk production on farms make it possible to use various technical and organisational solutions on farms. Depending on the labour resources, capital resources and land resources and goals of farmer solutions are offered accounting for the limitations. In practice, it often boils down to making a choice of:

1) a type of a building in which animals are to be housed (tethered or stanchion barns, bedding or non-bedding barns etc.),

2) a method of milking (stall milking, milking parlour, rotary milking parlour, milking robots)

3) a method of feeding with fodders (a fodder wagon, feeding stations, a wheelbarrow).

Technical equipment used during labour is accompanied by questions about a rational level of animals' productivity together with intensity adjusted to it in a specific housing system. Questions arise as to the cows' milk yields and investment expenditure made with a view to producing them. In the KTBL methodology (solutions of 2012), specific technical and organisational solutions are offered for dairy cattle in most available technologies. It is possible to list 35 construction (technical) solutions of barns for dairy cows differentiated based on a number of parameters, i.a. the numbers of stalls for cows (from 58 to 492).

A KTBL system user, in the "construction costs" tab, has the possibility to make a detailed analysis of investment expenditure required to fund a specific construction type of the barn (together with equipment) and to determine running costs. After selecting a specific construction system, a situation sketch of a livestock building is displayed, followed by a description of technical parameters of the building. Next program tabs offer a calculation of detailed investments required to develop a specific livestock building. They are precisely broken down by respective stages of construction and equipping. Apart from investment expenditure, it is possible to determine in the program yearly running costs. These costs include the following. Depreciation costs. They are calculated based on a flat rate method, depending on the anticipated useful life. Elements of the building and its permanent equipment are divided into three groups. The first group includes fixed assets, whose 
anticipated useful life is the longest (30 years). The second and third groups encompass fixed assets with shorter useful life, 15 and 10 years respectively. In the KTBL program elements of the building are automatically assigned to the three mentioned groups. Costs of repairs. They are calculated depending on the value of respective elements in the previously specified three groups. In case of the group of fixed assets expected to have the longest useful life it is assumed that costs of repairs will constitute $1 \%$ of their value. In case of the remaining two groups -2 and 3\% respectively. Costs of insurance. It is assumed that they will reach the level of $0.2 \%$ of the building value with fixtures. Costs of an interest rate of the capital engaged. It is proposed to establish them on 50\% of investments. Annual interest rate is $6 \%$.

Table 2. A statement of milk production revenues and costs in a selected production technology in the KTBL system

\begin{tabular}{|c|c|c|c|}
\hline Specification & Number/Stall & Price (EUR) & Value (EUR) \\
\hline Milk $4.1 \%$ fat, $3.4 \%$ protein & $8500.00 \mathrm{~kg} /$ year & $0.28 \mathrm{EUR} / \mathrm{kg}$ & 2380.00 \\
\hline Calves - bullocks, weight $42 \mathrm{~kg}$ & 0.48 unit/year & 112.80 EUR/unit & 54.14 \\
\hline Calves - heifers, weight $38 \mathrm{~kg}$ & 0.48 unit/year & 49.60 EURunit & 23.81 \\
\hline Cull dairy cows & $112.33 \mathrm{~kg} /$ year & $2.11 \mathrm{EUR} / \mathrm{kg}$ & 237.02 \\
\hline Production of slurry - cattle & $19.00 \mathrm{~m}^{3} /$ year & $0.00 \mathrm{EUR} / \mathrm{m}^{3}$ & 0.00 \\
\hline Total revenues & & & 2694.97 \\
\hline Heifer, & 0.32 unit/year & $1480.00 \mathrm{EUR} /$ unit & 479.82 \\
\hline Hay silage, first crop & $5.55 \mathrm{t} /$ year & 43.00 EUR/ton & 238.65 \\
\hline Meadow hat, first crop & $0.38 \mathrm{t} /$ year & 94.00 EUR/ton & 35.72 \\
\hline Corn silage & $6.93 \mathrm{t} /$ year & 46.00 EUR/ton & 318.78 \\
\hline Concentrate for cows & $2.90 \mathrm{t} /$ year & $170.00 \mathrm{EUR} / \mathrm{ton}$ & 493.00 \\
\hline Mineral additives for cattle & $94.16 \mathrm{~kg} /$ year & $0.50 \mathrm{EUR} / \mathrm{kg}$ & 47.08 \\
\hline Drinking water for animals & $29.42 \mathrm{~m}^{3} /$ year & $1.80 \mathrm{EUR} / \mathrm{m}^{3}$ & 52.96 \\
\hline Technological water & $3.70 \mathrm{~m}^{3} /$ year & $1.80 \mathrm{EUR} / \mathrm{m}^{3}$ & 6.66 \\
\hline Straw bales & $0.55 \mathrm{t} /$ year & $90.00 \mathrm{EUR} /$ ton & 49.50 \\
\hline Electricity & $50.00 \mathrm{kWh} /$ year & $0.17 \mathrm{EUR} / \mathrm{kWh}$ & 8.50 \\
\hline Vet, doctor of insemination & 1.00 unit/year & 75.00 EUR/unit & 75.00 \\
\hline Foot correction & $1.00 \mathrm{unit} / \mathrm{year}$ & 20.00 EUR/unit & 20.00 \\
\hline Identification of animals & 1.00 unit/year & 5.04 EUR/unit & 5.04 \\
\hline Disinfectants & 1.00 yera & 2.50 EUR/unit & 2.50 \\
\hline $\begin{array}{l}\text { Charges for control of breeding } \\
\text { performance }\end{array}$ & & 7.82 EUR/unit & 7.82 \\
\hline Insurance & & $3.50 \mathrm{EUR} /$ unit & 3.50 \\
\hline Utilisation of dead animals & & 5.50 EUR/unit & 0.52 \\
\hline Costs of equity & $1162.48 \mathrm{EUR} /$ year & $0.04 \mathrm{EUR} / \mathrm{EUR}$ & 46.50 \\
\hline Total direct costs & & & 1891.55 \\
\hline Direct surplus & & & 803.42 \\
\hline Variable costs of machines & & 353.98 EUR/unit & 353.98 \\
\hline Variable costs of human labour & $0.00 \mathrm{mh}$ & $7.00 \mathrm{EUR} / \mathrm{mh}$ & 0.00 \\
\hline Costs of services & & 0.00 & 0.00 \\
\hline Total variable costs & & & 2245.53 \\
\hline Gross surplus & & & 449.44 \\
\hline Fixed costs of machines & & 173.96 EUR/unit & 173.96 \\
\hline Fixed costs of human labour & $34.45 \mathrm{mh}$ & $15.00 \mathrm{EUR} / \mathrm{mh}$ & 452.31 \\
\hline $\begin{array}{l}\text { Surplus over direct costs and labour } \\
\text { performance }\end{array}$ & & & -176.83 \\
\hline Costs of buildings and their equipment. & & 573.16 EUR/unit & 573.16 \\
\hline Surplus over individual costs & $\mathrm{X}$ & $\mathrm{X}$ & -749.99 \\
\hline
\end{tabular}

Source: own study based on http://daten.ktbl.de/dslkrtier/postHv.html 
Having defined investment expenditure related to a specific system of dairy cows' housing a user of the planning data set in the KTBL system can start to precisely determine costs and revenues arising in milk production. For this purpose, s/he refers to the tab of revenues and costs in animal production. S/he selects an animal species, production direction, animal housing system, and the level of their yields. In the analysed system, potential of animal yields are limited. They are limited to three general statements: small, average and high.

A KTBL system user has the possibility to follow standard revenues and costs of milk production in available variants of dairy cattle raising technologies. The limited length of this paper allows to present only one dairy cattle raising system. It is a raising system of German black and white dairy cattle with a significant share of the HF breed in the genotype. The animals are housed in a stanchion, box, non-bedded barn prepared for 108 units. The barn is equipped with a herringbone milking parlour ( 2 x 6 milking stalls). Animals remain in the barn throughout the whole year, having a possibility to use runs. In the presented system average yields of animals are defined, which corresponds to annual cows' milk yields at the level of $8500 \mathrm{~kg}$ of milk with an average $4.1 \%$ fat content and $3.4 \%$ protein content. It was defined that the average weight of dairy cows was at the level of $700 \mathrm{~kg}$, intercalving period 417 days and calculations were performed for cows with 2.7 lactations. The first stage of the calculation is to assess potential revenues. As the data presented in Table 2 reveals, it includes the value of: milk, cull dairy cows and born calves. Quantitative parameters result from the adopted production technology.

A next step in the analysed calculation involves precise determination of all direct costs. They include all costs, which can be easily assigned to the calculated activity. In the KTBL methodology a production technology is handled in a very detailed manner and all costs (even the lowest ones) are identified (e.g. costs of dead animals utilisation, electricity, straw, corporate membership fee, costs of identification of animals). All prices result from market prices. Even costs of roughage (hay, hay silage, corn silage) are calculated based on market prices. A difference between revenues and direct costs is defined as - a part of costs after covering direct costs - a direct surplus (Direktkostenfreie Leistung). A next stage in the calculation entails determination of a gross surplus (Deckungsbeitrag).

In the methodology proposed by KTBL it is calculated as a difference between revenues and variable costs. A sum of direct costs and variable costs (which are not direct costs) of machines, human labour and services constitute total variable costs of a selected activity. At this stage of presentation it must be emphasized that in the methodology of the analysed statement an assumption is made that costs of machines operation can be divided into relatively fixed ones (depreciation, insurance, ongoing maintenance and interest of the engaged capital) and variable costs (use of fuel, lubricants, oils and repairs). At this level of calculation, a farmer obtains information about whether revenues cover costs dependent on changes in production volumes. It becomes clear whether it is worth continuing production (if it generates low profitability) or it is better to abandon it. In the analysed case, a direct surplus amounts to EUR 449.44 and a farmer obtains information that despite the negative income it is worth running the production. In the analysed calculation a next steps involves determination of fixed costs of machines, equipment and tools and fixed costs of human labour. The costs arise due to the adopted production technology and the used technical measures. In the last stage of the statement remaining fixed costs, which include: costs of buildings, legal costs and land transactions costs are subtracted. In the analysed example, when all costs are subtracted from total revenues, it turns out that the result is negative. 


\section{SUMMARY AND CONCLUSIONS}

Planning is still an important element of management. As studies carried out at the Department of Economics and Organisation of Enterprises at Warsaw University of Life Sciences reveal, Polish farmers (regardless of their education, age, farm area and keeping accounts) believe that planning is necessary. They justify this fact in first place with better organisation of work and opportunities to earn higher income. In practice, in most cases, farmers work out strategic plans, being long-term plans, and operational plans, which are short-term. Developed strategic plans depict a vision of a farm in the next few years and investment activities. This point is presented relatively in a general manner. It boils down to determining volumes of the production run. Operational plans are more concrete. They are frequently short-term (monthly, quarterly, annual) plans. Their most important element is a cash flow statement. There is an increasing number of electronic tools available on the market which support planning on farms. One of them is the American "FINPACK" program.

Summing up the issue of planning on farms it can be concluded that:

- At times of relatively low profitability of agricultural production, farmers have to plan their activity. It is a relatively complex task due to the character of agricultural production. On family farms, it is advisable to start the planning process from defining goals of a family, i.e. goals of a household.

- Farmers have to know precisely the costs expensed on a specific activity and potential generated revenues. They must have the possibility to compare achieved results on their farms with potential (standard) results arising from a rational production technology. They have to think over reasons for differences and eliminate them.

- Farmers, under present conditions (globalisation), must have the possibility to compare and choose a production technology out of the available ones (at a certain time), which from their own perspective - is the most attractive. To be able to make right decisions under a specific technology, they must have information about investment expenditure and production costs. There is a need for higher involvement of science (scientists) in the transfer of modern solutions into agricultural practice together with an economic assessment of their usability.

- Technical progress with regard to data collection and information sharing makes it possible to prepare a database, available on the Internet, useful for planning on farms. It is exemplified by German solutions provided via KTBL.

- A complex agricultural policy of the EU (specific activities and measures) must be based on reliable standard parameters to be efficient. To use EU fund monies in the most efficient manner there is a need for well prepared activity plans and a possibility of assessing them (standard parameters).

- European countries, including Poland, which do not have specific parameters for agricultural production (but decide to support it) should develop such a system as fast as possible. While making decisions about directions of supporting farms it is not possible to rely exclusively on information from FADN - which is historical and does not account for the issue of reasonableness of activities on farms (mistakes in management of farms).

\section{REFERENCES}

1. Bereżnicka, J. (1998). Kierunki zmian w systemie planowania rodzinnych gospodarstw rolniczych, Zagadnienia Doradztwa Rolniczego, 3/98, Poznań.

2. Bereżnicka, J. (2000). Metody i zakres planowania w gospodarstwach rolniczych, Ph.D. dissertation. 
3. http://daten.ktbl.de/baukost09/ (KTBL 2011).

4. Jarugowa, A, Sobańska, I, Sochacka, R. (1994). Metody kalkulacji. Koszty, ceny, decyzje, Warszawa: PWE.

5. Kowalczyk, S., Sobiecki, R. (2011). Europejski model rolnictwa wobec wyzwań globalnych, Zagadnienia Ekonomiki Rolnej, Wydawnictwo IERiGŻ, zeszyt 4.

6. Maniecki, F. (1976). Organizacja $i$ planowanie pracy wykonawczej $w$ rolnictwie, Warszawa: PWRiL.

7. Manteuffel, R. (1967). Plan i jego rola w rolnictwie oraz w przedsiębiorstwie rolniczym, Zagadnienia Ekonomiki Rolnej, 5.

8. Manteuffel, R. (1979). Ekonomika i organizacja pracy wykonawczej $w$ rolnictwie, Warszawa: PWRiL.

9. Manteuffel, R. (1987). Filozofia rolnictwa, Warszawa: Państwowe Wydawnictwo Naukowe.

10. Manteuffel, R. (1979). Ekonomika i organizacja gospodarstwa rolniczego, Warszawa: PWRiL.

11. Group editing, Ziętara W. (Ed.) (1994): Rachunek ekonomiczny i analiza finansowa w przedsiębiorstwie rolniczym, Warszawa-Brwinów.

12. Group editing, Woś A. (Ed.) (1996), Agrobiznes - mikroekonomia, Vol. 2, Warszawa: Wydawnictwo Key Text.

13. Rembisz, W. (2008). Mikro i makroekonomiczne podstawy równowagi wzrostu w sektorze rolno - spożywczym, Wydawnictwo Vizja Press\&IT

14. Stoner, J.A.F, Freeman, R.E., Gilbert, D. (2011). Kierowanie, Warszawa: Polskie Wydawnictwo Ekonomiczne.

15. Tomczak, F. (1998). hasło ,gospodarstwo rodzinne”. In Encyklopedia Agrobiznesu, Warszawa: Wydawnictwo Fundacja Innowacja.

16. Tomczak, F. (2004). Od rolnictwa do agrobiznesu Transformacja gospodarki rolniczożywnościowej Stanów Zjednoczonych Ameryki Pótnocnej, Warszawa: Szkoła Główna Handlowa Oficyna Wydawnicza.

17. Wilkin, J. (2005). Rolnictwo a społeczeństwo - ewolucja funkcji i relacji. In Rosner, A. (Ed.) Uwarunkowania $i$ kierunki przemian społeczno-gospodarczych na obszarach wiejskich, Warszawa: Wydawnictwo IRWiR.

18. Ziętra, W. (1998). Ekonomika i organizacja przedsiębiorstwa rolniczego, Warszawa: Wydawnictwo FAPA.

19. Żuk, J. (1986). Zadania z organizacji pracy $w$ gospodarstwie rolniczym, Warszawa: PWRiL. 